\title{
To the Problem of Integrative (Complex) Type of Understanding Law
}

\section{Vladimir Valentinovich Kozhevnikov}

Department of Theory and History of State and Law, Omsk State University Dostoevsky, Omsk, Russia

Email:kta6973@rambler.ru

\section{Abstract:}

This scientific article analyzes the positions of scientists in relation to the integrative (complex) type of legal understanding. Arguments of its opponents and supporters, advantages, as well as certain interpretations of law from the standpoint of this approach are given. The groundlessness of identifying an integrated approach with a broad understanding of law is emphasized.

Keywords:

legal understanding; integrative understanding of law; opponents of this approach; supporters of an integrative approach; a broad understanding of law

\section{Introduction}

The question of understanding law is important not only theoretical, but also practical. A number of other general theoretical questions depend on the solution of this complex issue. One of the classical types of understanding of law, in addition to the normative, natural law, philosophical, sociological, according to a number of scientists, is the integrative (complex) type.

\section{Research Methods}

When preparing a scientific article, the following methods were used:

1. General philosophical (dialectical-materialistic), which is used in all social sciences;

2. General scientific (analysis and synthesis, logical and historical, comparisons, abstractions, etc.), which are used not only by the theory of state and law, but also by other social sciences;

3. Special methods (philological, cybernetic, psychological, etc.), developed by special sciences and widely used for the knowledge of state and legal phenomena;

4. Private scientific (formal legal, interpretation of law, etc.), which are developed by the theory of state and law.

\section{Discussion}

\subsection{General Characteristics of the Positions of Scientists of the Relative Integrative Type of Understanding of Law: For and Against}

There are several positions regarding integrative legal understanding. So, Elizaveta Alexandrovna Frolova identifies two mutually exclusive approaches. 


\section{Polit Journal: Scientific Journal of Politics \\ ISSN: 2775-5843 (Online), 2775-5835 (Print)}

Vol. 2, No. 1, February 2022, Page: 1-11

Email: politjournal2@gmail.com

First, the point of view on the need to create a unified (integrative) understanding of law. This is supposed to be done within the framework of the new normativism or libertarian legal theory, or as a result of an integrative approach, or within the framework of one of the classical theories of law. The search for such a comprehensive definition suggests, the author explains, that all other definitions of law are obviously erroneous.

Secondly, judgments about the fundamental impossibility of finding a single definition of law due to the complexity and multidimensionality of the latter. Therefore, it is proposed to consider the concept of law as a set of competing concepts and the possibility of parallel types of legal understanding [1].

However, the analysis of the various positions of theoreticians allows us, in our opinion, to single out not two, but three approaches in assessing the integrative approach of legal understanding.

\subsection{Opponents of Integrative Legal Thinking}

The first approach is represented by those scientists who fundamentally oppose the construction of law, built on the basis of integrative legal understanding. For example, such a position, which rejects the desire to integrate different approaches to understanding law, the possibility of combining them and developing a single (integrative, multidimensional, etc.) concept of law, is taken by Natalia Vladimirovna Varlamova, who believes that the difference between two basic types of legal understanding - positivist and non-positivist - essential and irresistible, because within the framework of the first priority is given to the formal signs of law, within the framework of the second - to meaningful ones. And this difference is manifested not only in theory, but also in practice.

Of course, the author argues, today there are few positivists who dare to repeat after Hans Kelsen that the content of the Constitution and laws is not important for them, without denying the significance of the substantive requirements for law (justice, humanism, democracy, etc.). They, nevertheless, see its distinguishing feature in official recognition and powercompulsory provision. In practice, this means that in the event of a discrepancy between the law and any principles and requirements that it actually must comply with, it is necessary to follow the law, and not these principles and requirements. Natalia Vladimirovna Varlamova draws attention to the fact that supporters of the non-positivist type of legal understanding in such a dilemma will be guided by legal principles and requirements, and the law that does not correspond to them will be refuted as an offender, because for them the main thing in law is its content. In conclusion, the author concludes that any attempts to synthesize the indicated types of legal understanding, being brought to their logical end, inevitably turn out to be an apology for one of them, usually positivism [2].

Opponents of integrative legal thinking, evaluating various kinds of definitions of the concept of law from the standpoint of this approach, point out that their methodological shortcoming is that they try to cover with their help as proper legal phenomena in the legal sense, the ideas about which are very specific and do not cause serious disputes (for example, , subjective legal law, positive law), and those social phenomena that cannot be regarded as law in the legal sense (such as natural law, as legal awareness - intuitive law, as "living", social law - the established order of relations, etc. .d.). Of course, scientists believe that in real social life all these phenomena form a complex interacting system, exerting a certain influence on each other, which legal science will be able to comprehend only in conjunction with other social sciences. But the 
fact that objective and subjective law should act as its own (specific) subject of knowledge of the theory of law cannot be doubted. No other science can claim its exclusive study, while natural law, intuitive or social (informal) law can and should be studied by all social sciences. That is why, it is concluded that the so-called integrative definitions of law "do not take root" in the theory of state and law. In them, the term "law" is used to reflect various kinds of social phenomena, although they are closely related in public life [3].

Critically evaluating the definition of law developed by Gennady Vasilyevich Maltsev, according to which "law as a normative and regulatory system is a set of norms, ideas and relations that establishes the order of organization, control and protection of human behavior supported by the means of power" [4], Orest Vladimirovich Martyshin wrote the following: "If norms, ideas and attitudes coincide, are in harmony, such a definition is convincing. But when deep contradictions arise between them, the totality, and with it the definition, loses its core, breaks up into its component parts.

In general, opponents of the integrative approach to legal thinking summarize that the desire to create a universal definition of law is not feasible either theoretically or practically.

Within the framework of legal science, the concept of objective law still remains the starting point, because only the latter is an independent legal phenomenon both in terms of legal content and in terms of official form [2].

\subsection{Characteristics of a Moderate Approach to the Integrative Type of Legal Understanding}

Supporters of the second, moderate approach are scientists who, in principle, recognize the integrative type of legal understanding, but under certain conditions. So, Mikhail Nikolaevich Marchenko, focusing on the positivist concept and theory of natural law, notes that legal positivism was and, unfortunately, still dominant in the domestic legal ideology, in which the concept and role of law was often reduced to elementary "orders" of the state and the legal status of a person and citizen - to the legal status of a loyal subject. The scientist opposes attempts to introduce elements of natural law into positive law, which were mechanical in nature. In his opinion, the Constitution of the Russian Federation of 1993 can serve as a vivid example of such a negative experience, which, being by its nature and character a purely positivist political and legal act, mechanically includes a number of disparate, conceptually unrelated natural law provisions.

Meanwhile, in his opinion, the further development of legal theory in each country is seen in an organic combination of vital and practically significant provisions of the theory of natural and positive law, in the consistent filling of the content of positive law with the spirit and principles of natural law [2].

I think that in this respect one should pay attention to the point of view of Orest Vladimirovich Martyshin, who believes that "the theory of natural law is quite compatible with the analysis of the system of positive law, if its place is correctly determined, if considered as an ideal. Insoluble problems arise when natural law is understood not as an ideal, but literally, i.e. issued as valid law. This creates confusion.' [5] In another work, the scientist directly writes that "although each of ... the main types of understanding has its own sphere of action, there are points of contact between them, a kind of boundary zone, indicating the organic connection of these phenomena and" opening gateways "for the influence of ideal understanding on positive law"[6]. 
Valentina Viktorovna Lapaeva writes that each of the approaches she identified has important cognitive capabilities that are in demand in modern social and legal practice. It is this circumstance, the author believes, that largely determines the numerous attempts to build the socalled integrative concepts of legal understanding, trying to combine different approaches to the understanding of law. However, she emphasizes that "by simply combining sociological and legalistic or legalistic and natural law approaches to understanding law, we will not get a "working", i.e. giving an increase in scientific knowledge, a theoretical construction, but we will only multiply the shortcomings inherent in each of these approaches separately. And then she makes an important and fundamental conclusion that "the variety of different characteristics and definitions of law, developed within the framework of various approaches to legal understanding, must be linked within the framework of a holistic, logically consistent concept that expresses the essential feature and principle of law." And a logically consistent conceptual basis for connecting different types of legal understanding can only be a philosophical legal understanding, which recognizes that the law has essential characteristics that fix the difference between law and other social phenomena"[7].

\subsection{Proponents of an Integrative Type of Legal Understanding}

The third approach combines the views of those scientists who believe that an integrative type of legal understanding has the right to exist. At the same time, it should be borne in mind that the integral idea of understanding law did not appear out of nowhere, but has its own long history [8].

It seems that at one time the possibility of using an integrative approach in developing a definition of the concept of law was not rejected by Vladik Sumbatovich Nersesyants, who believed that "the combination of various definitions of law in one concept means their unification (combination, compaction, synthesis, concretization) on the same basis, since we are talking about various manifestations and definitions of a single legal entity. Moreover, the scientist clarified, these various definitions of law (due to their conceptual and essential unity) not only complement, but also imply each other, which gives a logical basis for the definition of the general concept of law. Thus, the author continued, even the briefest definition of the general concept of law should include at least two definitions, the first of which would contain a characterization of law (before and independently of the law) as a specific social phenomenon, and the second would characterize law in its official recognition and universal validity (right as a special establishment, law). At the same time, it was emphasized that the first of the characteristics is most adequately expressed in the definition of law as objectively conditioned, having a social class character and expressing the requirement of fairness of the general measure (form, norm) of freedom and equality, and the second - in the definition of law (law in the form of law). ) as an official (state-powerful, expressing the will of the ruling class, formally defined and obligatorily defined) expression and establishment of law endowed with legal force. "Obviously," Vladik Sumbatovich Nersesyants wrote in conclusion, "that the second definition significantly complements, develops and concretizes the first, and in their unity they express the most essential in the general concept of law as a historically changeable, objectively determined, fair general measure determined by social class relations and equality, receiving by means of official expression a generally binding force"'[9].

It is interesting to note that supporters of the integrative type of legal understanding in substantiating their position give appropriate arguments, offering one or another version of the concept of law. A supporter of an integrative approach to the concept of law is Elena Andreevna Lukasheva, who believes that the issue of legal understanding is extremely important for domestic jurisprudence, since it directly goes to the value orientations of society, and it needs an 
impeccable legal basis, the quality of legislation, which must meet the basic legal principles and ultimately focused on the person, the protection of his rights and freedoms. The author notes that among the whole variety of schools and directions, through the centuries, the main opposition of positions takes place: natural law and positivist. Thus, the development of constitutionalism in the current conditions shows that states, recognizing the natural law doctrine, do not at all reject the registration of human rights and freedoms in positive legislation. This fully applies to the most important international legal documents on human rights. Summarizing the above, the following conclusion is made: “... the wealth of law is spread as a result of applying a multidimensional approach to it. It is important to analyze law as a specific phenomenon that stood out from the system of other social regulators.

Nikolai Andreevich Pyanov, evaluating the integrative approach, drew attention to the fact that in modern domestic theory you will not find any of the approaches in its pure form. It is the integrative approach that is called upon to unite everything valuable that is inherent in the normative, sociological, and moral approaches" [10].

The integrative approach is also impressed by Vladimir Ivanovich Chervonyuk, who gives a number of weighty arguments in its favor. So, the scientist argues, one of the trends in the modern development of jurisprudence is a deepening of the idea of law as a whole. The task is to restore on a broader theoretical basis the unity of all aspects of law dissected by analysis, to present it as a whole with the help of synthesis (integration), to show the essence and interaction of the noted parties, the place and measure of each of them. From the standpoint of an integrative approach to law, in his opinion, everything is equally important. From this point of view, law is a legal idea embodied in a norm (law) and actual lawful actions - a legal order. In this case, the following arguments require special attention:

1) an integrative approach allows a more accurate approach to assessing the objective and subjective in law, to comprehend the role of actual lawful activity in the law-forming process, and, consequently, the nature of the so-called "actual law", without rejecting and not referring to "pre-legal" factors that which was originally endowed with legal properties;

2) the approval of an integrative approach to law is of great ideological significance, orienting mass and professional legal consciousness to the understanding that legal regulation of relations and actions is possible only where objectively there is provability and enforceability of legal relations by means of the legal process, that the operation of law implies certain conditions, requires the necessary resources, the presence of special structures capable of accepting the right and, if necessary, forcing its execution;

3) Within the framework of an integrative approach, each of the types of legal understanding (natural-legal, normative and sociological - Vladimir Valentinovich Kozhevnikov). acts as a counterbalance to the other. Thus, it becomes possible to exclude the absolutization of any one view of law. Vladimir Ivanovich Chervonyuk especially emphasizes that the integrative approach does not divide the above approaches into different poles, but synthesizes their advantages on a common methodological basis, warns against extremes. The core of integrative understanding, its systematizing quality is the idea of the action of (acting) law. Moreover, it is important, in our opinion, is the statement that the integrative approach is a methodological concept for the convergence of various concepts of law, allows you to take into account the requirements of the completeness and comprehensiveness of scientific analysis and assessment of the nature of law, determining the sources, mechanisms and patterns of its action in society [11]. 
Oleg Yuryevich Vinnichenko and Vladimir Ivanovich Popov spoke very clearly on the problem under consideration, believing that the value of law "consists in the plurality of approaches that are not without the methodological possibility of synthesis, integration"[12]. Even earlier, Vitaly Vasilievich Oksamytny substantiated his position in the same sense, saying that "the law is always somewhat unsatisfactory, imperfect, requires different changes and unequal transformation depending on the given place and time. Therefore, for scientific purposes and in the interests of effective lawmaking and law enforcement, one should welcome different approaches to law, different definitions of law and the desire to synthesize them within a single concept"'[13].

Developing these provisions, Valery Vasilyevich Lazarev writes that broad definitions of law (we are talking about an integrative type of legal understanding - Vladimir Valentinovich Kozhevnikov) are good because they focus on the consideration of the life of law in legal relations, legal consciousness, law enforcement acts, and subjective rights [14]. From the standpoint of a scientist, the integrative definition of law is as follows: "law is a set recognized in society and provided with official protection of the standards of equality and justice that regulate the struggle and harmonization of free will in their relationship with each other" [15].

As an integrative understanding, we evaluate the interpretation of law by Vladimir Konstantinovich Babaev: "... this is a system of normative guidelines based on the ideas of human justice and freedom, expressed mostly in legislation, and regulating social relations" [16].

Sergei Sergeevich Alekseev believed that "questions of the general concept of law are among the most important in legal science. They invariably remain the subject of close attention of scientists, creative, comprehensive discussion. Among a number of constructive directions that make it possible to deepen and develop the general concept of law from the point of view of the latest philosophical, general scientific ideas, achievements of legal thought in the context of the problem of integrative legal understanding, it seems important to highlight the following: "deepening the concept of law as a legal phenomenon in its relationship with that non-legal a phenomenon in the life of society, which can be designated as directly social claims (and also, it should be added, social duty). Without identifying, clearly distinguishing between the one and the other, without allowing their confusion, it seems extremely important to reveal their special roles in the expression and mediation of social freedom, activity, responsibility in a class society, and most importantly, their interaction, partial interpenetration" [17].

Vladimir Ivanovich Shepelev, referring to the problem of legal understanding, believes that in the variety of approaches to legal understanding there are many gaps, elements of the farfetched and opportunistic, protrusion of some properties and ignoring others, but at the same time the content of that valuable thing that, of course, should be taken into account, taken into account when definition of the concept of law. The author is convinced that there is a need for a synthesis of various judgments that are of interest for a more or less objective understanding of law, perhaps the integration of the most essential characteristics of law as a social phenomenon, a social phenomenon.

Assessing various definitions of integrative legal thinking, both those that were carried out earlier and others, for example, "law is the order of social relations that determine the behavior of people in accordance with the state expressed dominant will and reflected in the legal consciousness of society, which are regulated by a complex system of generally binding principles, normative prescriptions and actions protected in necessary cases by state coercion and aimed at establishing a solid legal order"[18] or "law is normatively fixed justice, consisting in the implementation of a public compromise"[19], the scientist emphasizes that the judgments 
expressed by different authors about the understanding of law have something common that integrates the beginnings of the natural, normative, sociological theory of law, reflecting its certain value facets [20].

It seems that Ivan Vladimir Timoshenko's point of view is interesting, according to which the analysis of various theories considering the essence of law leads to the formulation of two main approaches to its concept.

First, law is understood as a system of rules of conduct issued by the state, other organizations, guaranteed for execution. This is the so-called narrow, monistic understanding of law.

The second - the right, understood as a measure of individual freedom, correlates with justice and equality, freedom of choice, the interests of different individuals, etc. This is the socalled pluralistic, broad understanding of law. According to the author, the interaction of these two approaches makes it possible to get as close as possible to the essence, and, accordingly, to the definition of law, which is formulated as follows: "law is a system of regulation of social relations that is conditioned by the nature of man and society, expressing the freedom of the individual and affirming justice, which is characterized by normativity, formal certainty in official sources and security with the possibility of state coercion"'[21]. True, if we critically evaluate such an understanding of law, it is embarrassing that the signs of positive law are arbitrarily, and, it seems, unreasonably transferred to its ideal part (in this case, to philosophical legal understanding - Vladimir Valentinovich Kozhevnikov).

We believe that the considered positions of Russian theoreticians give a clear idea of the attitude towards the integrative (complex) approach of legal understanding.

As for our position, it is more inclined towards the second, moderate approach, which avoids extremes in assessing integrative legal understanding [22]. In any case, when resolving this problem, we proceed from the fact that modern legal understanding should be based on the idea that law is an integral part of culture, and in this sense, materialistic and ideal judgments about law should not be opposed. In addition, it should be borne in mind that the relationship between the requirements of law (ideal nature) and its manifestation in the content of public institutions (material embodiment) is determined by the fact that the current law is not only a sphere of being, but also at the same time a part of the consciousness of a society that is at a certain stage. its development (estate society, society of formally equal persons, civil society with stateguaranteed rights and freedoms). Given the above provisions, Elizaveta Alexandrovna Frolova, with whose position we are in solidarity, argues that "law is a multilateral phenomenon: it not only belongs to the sphere of causal phenomena (for example, economics), but is a product of the human spirit (for example, ethics, psychology, etc." Therefore, the main conclusion is made: "law as a phenomenon of the social world is one, but as a sphere of spiritual life it is heterogeneous" [1].

\subsection{Advantages of an Integrative Type of Legal Understanding}

A supporter of the integrative approach of legal understanding emphasizes that it fits into the pluralistic perception of the world, meets the modern demands of the time, inspired by the processes of globalization. This approach has a number of positive aspects: 1) it removes the tension in opposing one theory to another, recognizing each of them as its relative truth; 2) allows constructing a general definition of law, in which there is a full coverage of legal values known to history, inherent in different civilizations; 3) highlights among all the essential values, 
that is, without which law would not be law, recognizing among them equality in the free manifestation of the individual; 4) does not focus on either the creators of law or its sources, recognizing here the diversity of both; 5) for utilitarian, pragmatic purposes, allows a conventional beginning in the recognition of a certain value by law for a certain place and time; 6) allows you to look at the law through the eyes of a person who knows it, through the eyes of a practitioner and the eye of a philosopher, without questioning the value and, at the same time, the difference in goals in each of these cases.

\subsection{Identification of the Integrative Type of Understanding of Law with Its Broad Understanding}

In our opinion, it is difficult to agree with those scientists who identify the integrative (integral) understanding of law with the so-called broad understanding [23]. So, bearing in mind such an identification, Orest Vladimirovich Martyshin believed that law is understood not only as legal norms, but also as social relations (legal relations) arising in accordance with these norms, and ideas about what these norms (legal consciousness) should be [6].

The thing is that if a type is generally understood as "a form, a kind of something that has certain characteristics, as well as a pattern that corresponds to a known group of objects, phenomena [24], a type of understanding is a theoretical and methodological approach to the formation of an image law, carried out within the framework of a certain methodology of analysis from the standpoint of one or another theoretical vision of the problem [7], then the broad concept of law shows the existing elements of the content of law. For example, the wellknown theoretician Gennady Vasilievich Maltsev, considering law as a normative regulatory system, believes that the first is "a set of norms, ideas and relations (not legal relations - Vladimir Valentinovich Kozhevnikov), which establishes the order of organization, control and protection of human rights supported by the means of power behavior"'[4].

By the way, it should be emphasized that a "broad" legal understanding was formed in domestic science in the 60-80s. 20th century and opposes the "narrow normative" approach to law. This concept is based on the idea of law as a unity of legal ideas, norms and relations. Its supporters included ideas, norms, and relations in the content of law. This position was first substantiated in the works of Pyotr Ivanovich Stuchka, Evgeny Bronislavovich Pashukanis, and later developed in the works of Stepan Fedorovich Kechekyan, Andrey Andreyevich Piontkovsky, Alfred Krishyanovich Stalgevich, Nikolai Vasilyevich Vitruk, Valery Dmitrievich Zorkin, Vladimir Petrovich Kazimirchuk, Gennady Vasilevich Maltsev Roman Zinovievich Livshits, Elena Andreevna Lukasheva, Nikolai Ivanovich Kozyubra, Vladimir Alexandrovich Tumanov, Vladik Sumbatovich Nersesyants, Lev Samoilovich Yavich and other domestic scientists. Attention needs to be drawn to the provision according to which, within the framework of this approach, several directions were identified: one group of authors tended to reduce law to legal ideas (law - normatively expressed justice, measure, scale of freedom, etc.), another group understood law as ideas, norms and relationship; the third group identified law with the system of social relations. So, back in the late 30's and 40's. Alfred Krishyanovich Stalgevich, and in the 50s. Stepan Fedorovich Kechekyan and Andrey Andreevich Piontkovsky proposed to include in the concept of law, along with the norms of law, also legal relations, and then Yakov Filippovich Mikolenko - legal relations and legal consciousness. At the same time, legal relations and legal consciousness were considered by them as forms of implementation of legal, i. legislative norms. The general conclusion of the proponents of this approach was that law is not reducible to normative institutions. What is the advantage of the "narrow normative" approach (formal certainty, normativity) should also be recognized as the main omission for the "broad" legal understanding [25]. 
Note that the way Valery Vasilyevich Lazarev and Sergey Vasilyevich Lipen interpret the "narrow" and "broad" concept of law raises great doubts. Scientists believe that "the so-called "narrow" understanding of law is contained exclusively in regulations (or rather, in regulations Vladimir Valentinovich Kozhevnikov) issued by state bodies ... Supporters of the so-called "broad" understanding of law usually agree with the characterization of regulatory law as the main source of law. However, they also say that written law ... is not able to fully and adequately regulate social relations ... Therefore, a normative act is not the only source of law. Along with it, the rules of law are found in other sources of law, primarily in judicial and administrative practice. It seems that in the latter case, again, we are talking about a "narrow" (narrow normative) understanding of law, because any legal source of law, and not just a normative legal act, contains rules of law. As the authors rightly write, from the standpoint of a narrow normative approach, "law is a set of norms emanating from the state and protected by it"'[26].

Over the past century, the general understanding of law, implanted in the branch of legal sciences, is precisely its narrowly normative interpretation. This idea of law (positivist theory of law) was formed in Europe in the first half of the 19th century. The founders of this theory acted under the progressive slogan of the rule of law as a source of law, identified legal norms with the prescriptions of state power. In the Russian conditions of that time, the ideas of positivism had a positive connotation, since they expressed the demands of limiting autocracy, the rule of law.

At the same time, even then, some scholars pointed to the limited nature of positivism, its destructive influence on legal science. Thus, the domestic civil lawyer Yuri Stepanovich Gambarov wrote that the doctrine that fixes jurisprudence in the grip of the current legislation is not consistent with the entire history of law and that reducing all jurisprudence to the interpretation of current legislation "means to lead jurisprudence as a science to bankruptcy" $[27]$.

As in the Soviet era, the understanding of law "as a normative form of streamlining and stabilizing social relations protected by state coercion" remains dominant in jurisprudence at the present time [28]. Boris Ivanovich Puginsky, evaluating positivist ideas, points to the obvious enormous harm they cause to society and legal science. The author believes that positivism itself has long exhausted its cognitive and prognostic potential, has shown inability to creative scientific research. Under the pressure of normative ideas, legal science remains flawed, onesided, closed within the framework of a dogmatic study of legislative texts. "Irradiation with positivist ideas", according to the scientist, paralyzed the creative abilities of several generations of Russian lawyers, frozen legal practice into ice [29].

Mikhail Nikolaevich Marchenko drew attention to the fact that the analysis of numerous points of view and approaches that differed from each other to one degree or another, which arose in a relatively short period of time within the framework of a "broad" legal understanding, clearly showed that the proposed "broad" ideas about law and its corresponding definitions were not of any radical nature and, in essence, did not actually go beyond the official "narrow normative" idea of law [31].

Nikolai Ignatievich Matuzov looked at this problem somewhat differently, who, assessing the events in Russia in the early 1990s, wrote the following: "Who would have thought that the concept of a broad understanding of law, harmless at first glance, would be used in the most acute political battle to substantiate one of the conflicting parties of its "correctness" that the indicated (quite scientifically correct) idea objectively gives such a desired and necessary "trump card" to the hands of persons in power [32]. 


\section{Conclusion}

It seems that the stated author's position in relation to the integrative (complex) type of legal understanding will allow, firstly, to better understand this scientific approach; secondly, to critically evaluate those scientists who are trying to identify this approach with a broad understanding of law.

\section{References}

[1]. Frolova Elizaveta Aleksandrovna. Methodological bases for delimiting the concepts of law understanding//State and Law. 2000. No. 4. Pp.15, 63.

[2]. Basic concepts of law and the state in modern Russia (round table) // State and law. 2003.№5. Pp. 9-10, 18, 30.

[3]. Actual problems of the theory of state and law: textbook / otv. ed. Rosalina Vasilievna Shagieva. Moscow: Norma, 2011. Pp. 242, 243.

[4]. Maltsev Gennady Vasilievich. Understanding law. Approaches and solutions. Moscow: Prometheus, 1999.P.7

[5]. Martyshin Orest Vladimirovich. On the concept of the textbook on the theory of state and law // State and Law. 2002. No. 8. Pp.62, 64.

[6]. Martyshin Orest Vladimirovich. The concept and functions of law // Theory of state and law: textbook / ed. Orest Vladimirovich Martyshin. Moscow: Norma, 207.Pp. 248, 256.

[7]. Problems of the theory of state and law: textbook / ed. Vladimir Mikhailovich Syrykh. Moscow: Eksmo, 2008.Pp.31, 42-44.

[8]. Grafsky Vladimir Georgievich. Integral (synthesized) jurisprudence: an actual and still unfinished project //Jurisprudence. 2000. No. 3. Pp.49-64.

[9]. Nersesyants Vladik Sumbatovich. Law: variety of definitions and unity of the concept // State and Law. 1983. No. 10. P.30.

[10]. Pianov Nikolai Andreevich. Consultations on the theory of state and law: a study guide. Irkutsk, 2008. P.131.

[11]. Chervonyuk Vladimir Ivanovich. Theory of state and law: textbook. Moscow: INFRA-M, 2004.Pp.233-234.

[12]. Vinnichenko Oleg Yurievich, Popov Vladimir Ivanovich. Theory of state and law: textbook. Moscow: Prospekt, 2010. Pp. 219, 220.

[13]. Oksamytny Vitaly Vasilievich. Theory of state and law: textbook. Moscow: IMPEPUBLISH, 2004.P.323.

[14]. Theory of state and law: textbook / ed. Albert Galimzyanovich Khabibullin, Valery Vasilyevich Lazarev. Moscow: Forum, INFRA-M, 2009. P.270.

[15]. Theory of state and law: textbook / ed. Valeria Vasilievich Lazareva. Moscow: New lawyer, 1997. P.98.

[16]. Babaev Vladimir Konstantinovich. The concept of law // General theory of law: a course of lectures / ed. Vladimir Konstantinovich Babaev. Nizhny Novgorod: Nizhny Novgorod Higher School of the Ministry of Internal Affairs of Russia, 1993. P. 111.

[17]. Alekseev Sergey Sergeevich General theory of law: textbook. Moscow: Prospekt, 2008. Pp.81-82.

[18]. Fundamentals of state and law: textbook / ed. Vladimir Alekseevich Rzhevsky and Viktor Timofeevich Gaikov. Rostov n / D: Phoenix, 1995. P. 129.

[19]. Livshits Roman Zinovievich. Theory of law. Moscow: BEK, 1994. P.69.

[20]. Shepelev Vladimir Ivanovich. Understanding Law // Lyubashits Vladimir Yakovlevich, Smolensky Mikhail Borisovich, Shepelev Vladimir Ivanovich. Theory of state and law: 
textbook / ed. Vladimir Yakovlevich Lyubashits. Rostov n / D: Phoenix, 2006. Pp.273274.

[21]. Timoshenko Ivan Vladimirovich. Law and legal understanding // Lyubashits Vladimir Yakovlevich Mordovtsev Andrey Yurievich, Timoshenko Ivan Vladimirovich, Shapsugov Damir Yusufovich. Theory of state and law: textbook. Rostov n / D: March, 2003. P. 446.

[22]. Kozhevnikov Vladimir Valentinovich. To the problem of a complex type of understanding of law // Vestnik OmGU. Right. 2012. No. 2. Pp. 24-32.

[23]. Kozhevnikov Vladimir Valentinovich. "Narrow" and "broad" concept of law in Soviet legal science in the context of the analysis of modern problems of the integrative type of legal understanding//Modern Law. 2014.№4. pp.8-13.

[24]. Ozhegov Vladimir Ivanovich. Dictionary of the Russian langua Moscow: ge. Russian language, 1984. P. 692.

[25]. Igor Vladimirovich Goiman-Kalinsky, Galina Ivanovna Ivanets, Vladimir Ivanovich Chervonyuk. Elementary principles of the general theory of law: textbook / under the general editorship. Vladimir Ivanovich Chervonyuk. Moscow: Law and law, Kolos, 2003.Pp. 67, 70.

[26]. Lazarev Valery Vasilievich, Lipen Sergey Vasilievich. Theory of state and law: textbook. Moscow: Yurayt, 2010. Pp.227-228.

[27]. Gambarov Yuri Stepanovich. Civil law. General part: textbook / ed. Vladimir Alekseevich. Tomsinov. Moscow: Zertsalo, 2003.P.10.

[28]. General theory of state and law: an academic course in 2 volumes / ed. Mikhail Nikolaevich Marchenko. Moscow: Zertsalo, 1998. Vol.2. Right. P.4.

[29]. Puginsky Boris Ivanovich. Understanding law from the standpoint of modern civil law //Jurisprudence. 2007.№6. P.7.

[30]. Nersesyants Vladik Sumbatovich. Our path to law: from socialism to civilism. Moscow: Russian law, 1992. P. 286.

[31]. Marchenko Mikhail Nikolaevich. Problems of the general theory of state and law: a textbook in 2 volumes. Vol.2. Right. Prospekt, 2008.P.11.

[32]. Matuzov Nikolay Ignatievich. Actual Moscow: problems of the theory of law. Saratov: Saratov State University. Academy of Law, 2003. P.162. 